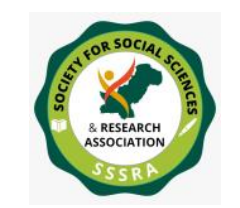

\title{
The Conundrum of Pak-Afghan Border: A Historical Perspective
}

\author{
Dr. Shehla Tehseen \\ Assistant Professor \\ Department of Political Science \\ University of Karachi \\ shehla.tehseen@uok.edu.pk
}

\begin{abstract}
The territory has remained a bone of contention between modern nation states. Pakistan and Afghanistan have also no exception from it. Pak-Afghan relations have been in turmoil since the day when Afghanistan refused to accept Pakistan as a country and voted against its newly independent neighbor in the United Nations. It all happened in lieu of that Afghanistan is of the view that the North-Western Frontier Province (NWFP), currently known as Khyber Pakhtunkhwa (KPK), Baluchistan and some areas of Punjab are the parts of Afghan territory. Afghanistan breached all the previous agreements made over the Durand Line calling it just an imaginary line. Based on this entire scenario, this research study analyzes the changing dynamics of Pak-Afghan relationships in different eras driven by different factors. It discusses the pre-colonial impacts on the relationship between the two countries, it also probes what happened right after 1947 and then highlights the impacts of 9/11 tragic events. Reviewing the existing literature and the opinions of different political scientists on this issue, this study discusses the historical background of Pak-Afghan borderland. Moreover, it also attempts to shed light upon the geostrategic importance of Pakistan and Afghanistan in the region so that the political decisions on the persisting issue are made in a way that they favor the interests of both the states. This paper also elucidates the literature available on the colonial legacy of the Durand Line.
\end{abstract}

KEYWORDS: Pak-Afghan Borderland, Durand Line, Pre-Colonial Impacts, Poisoned Legacy. 


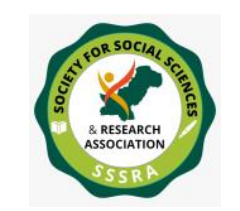

Pak. Journal of Int'L Affairs, Vol 4, Issue 2 (2021)

The Conundrum of Pak-Afghan Border ...

\section{INTRODUCTION}

Historically, Pakistan-Afghanistan experienced bumpy relations. The Soviet Invasion (1979-1989), the defacto Taliban regime (1994-2001) and post-9/11 developments could be regarded as some important events that have considerably tainted Afghanistan relations with Pakistan. It would not be wrong in saying that a sense of distrust prevail between Islamabad and Kabul. The Pak-Afghan border is found to be one of the most unstable yet strategically important since the Soviet invasion of 1979(Bashir \& Crews, 2012). Some of the principles on borderland have persisted over time, for example, providing sanctuary, however, an inevitable dramatic change was marked in its political economy (Hussain, 2017). The last three decades have been histrionic in a sense that the war in Afghanistan and the revolutionary shuffle in the political panorama of Pakistan have driven the dynamics of this borderland toward reorganization, both in the logic of scope and importance. The Pashtuns living on both sides of the border can claim the credit of this (Omrani, 2009).

Due to the vigorous role of Pakistan Army, the British style indirect rule had come to its de facto end in Pakistan, however, the state power of Afghanistan was found nowhere in the scene on borderland (Kundi M. A., 2016). The repeated military operations could not make any difference, as both Pakistan and Afghanistan kept on losing most of the ground and left the empty field to be inhabited by the Jihadist groups who kept on challenging the state and the tribal system (Rubin \& Siddique, 2006). Furthermore, the Pashtuns tribes had to forgo their ample monopoly over the smuggling business. The massive surge in the level of traded contraband could have been observed with the yearly exchange of billions of dollars. Due to the presence of refugees in the Arab Gulf, the commercial networks developed the wider geographic range. However,, the Pashtuns in Karachi got themselves highly into the business of transportation (Bashir \& Crews, 2012).

The religious schools or what we call Madrasas influenced the politics on both sides of the border and played a catalyst role in ensuring the social revolution (Chaudhry, 2017). Moreover, the Arab countries lend their hands for the support of the Salafist and the other Islamic strains in both the countries for their own favorable objectives (Haider, 2013). This research paper is though, an attempt to probe the history of Pak-Afghan borderland and the changing dynamics of the relationship between Pakistan and Afghanistan over time. It discusses the three important phases in the relationship of neighborhood countries including pre-colonial, post-1947 and post 9/11 impacts.

The most important part of this paper is the exploration of Durand line's legacy which was entitled as the Poisoned Legacy by Micallef (Micallef, 2015). Contextually, the 
British Colonial power drew the Durand line in order to keep the Czarist Russia at distant by declaring Afghanistan as a buffer state during the Great game of $19^{\text {th }}$ century. This line divides the region, formally known as Pashtunistan into two of which half of the area comes into the possession of Pakistan and half remains to be the part of Afghanistan. This partition made Afghanistan to lose her access to the Arabian Sea. Because of this and the other obvious reasons which are discussed in the fifth part of this study, Durand Line will be the core principle of Afghanistan's foreign policy in the upcoming decades and also will keep on defining and redefining the relationship of Afghanistan with Pakistan.

\section{PAK-AFGHAN BORDERLAND}

There are 1468 kilometers long border at the forefront of Baluchistan that connects Pakistan to Afghanistan. This is the point where Baloch and Pashtoon interact for several reasons (Kundi D. M., 2016). Four provinces of Afghanistan namely; Helmand, Nimroz, Kandahar, and Zabul are attached to Baluchistan.

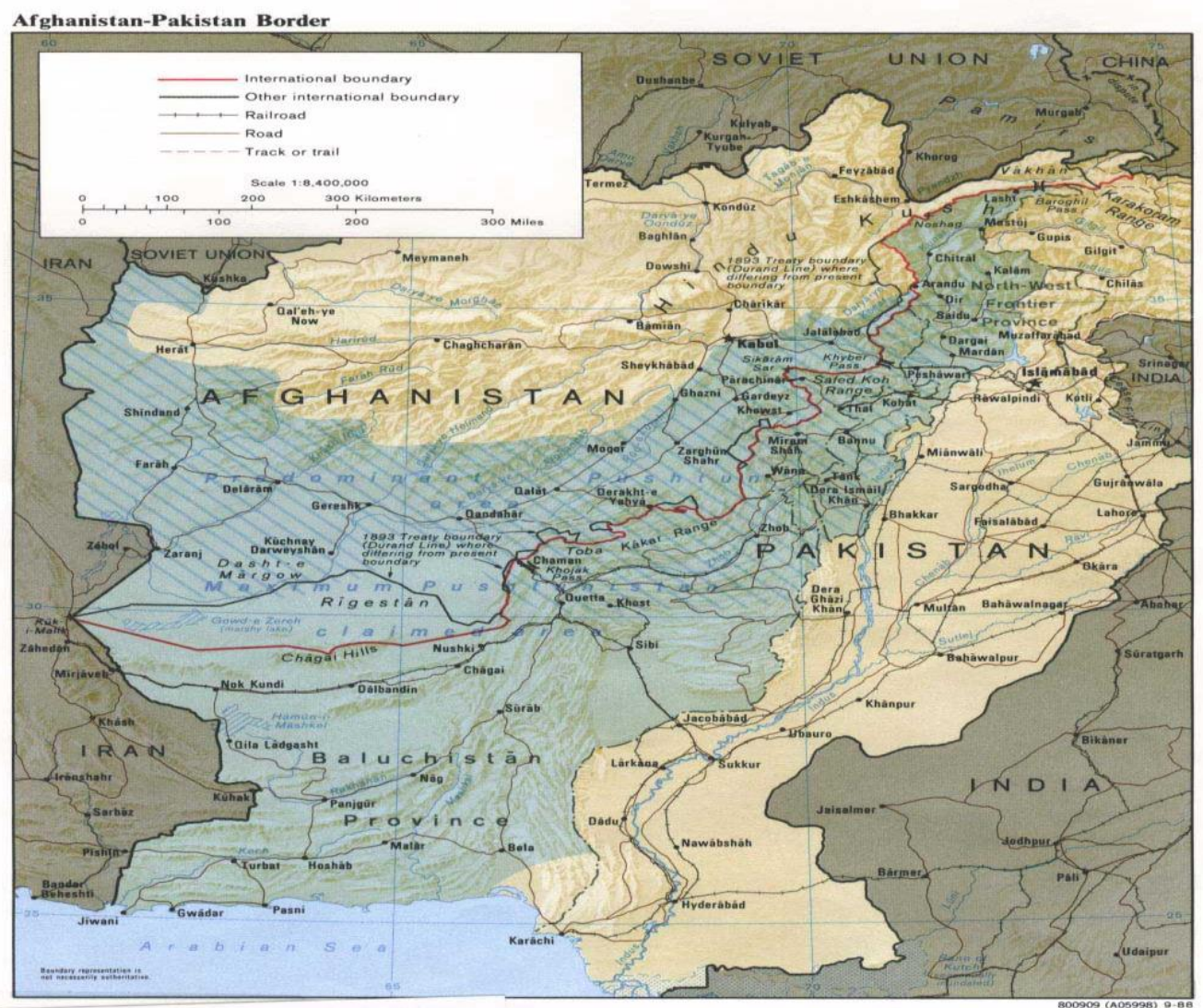

SOURCE: http://worldpress.org/specials/pp/afghan_pak_border_map.htm 


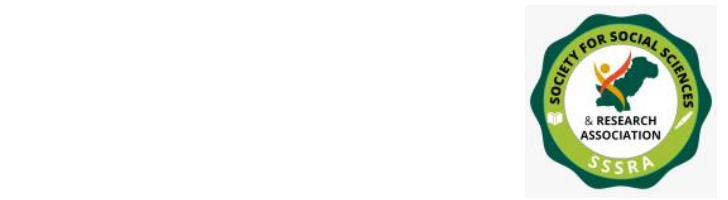

Pak. Journal of Int'L Affairs, Vol 4, Issue 2 (2021)

The Conundrum of Pak-Afghan Border ...

The interactions over the borderland are pushed back by different factors including socioeconomic ventures, cultural exchange, economic activities etc. It is hence a fact that the tribes residing there need this interaction to ensure the mutual support for each other to survive (Rais, 2017). This borderland has been discussed and the issues related to it are debated in political scientists' circles a lot. However, there is hardly any logical conclusion that is found in the literature. It is though important to understand the geographical locations of Pakistan and Afghanistan and their respective geostrategic importance in the region. To know it all is necessary to highlight the importance of both of these countries so that it becomes certain that the conflict must be resolved based on the fact that none of the states and their interests are marginalized.

\section{THE GEOSTRATEGIC IMPORTANCE OF PAKISTAN AND AFGHANISTAN IN THE REGION}

Geostrategic means the importance of a country on the basis of its geographical location within the region (Defence P. , 2013). It is important to understand the geostrategic importance of the states to analyze the geopolitics that stresses the role of the geographic factors on the power of the state. We in this article, are exploring the geopolitics of Pak-Afghan borderland, therefore, it is important to understand the geostrategic importance of both the countries so that the conclusion about the bilateral relationship between the neighboring countries come out to be in favor of both.

\section{PAKISTAN}

Pakistan lies in the region where it stands being significantly important economically, politically and strategically. It has been the part of the activities of the countries of great power for decades (Nytimes, 20). The country is located nearby the Gulf States, which are the producers of $65 \%$ of the world's total oil production (Opec, 2016). It is important for the proximity of great powers as it has neighbors like China and Russia (Yousaf, 2018). The US looks at Pakistan for its security and it is a gateway for them to enter Afghanistan for taking the war on terror on some concluding state (Reuters, 2018). Being a gateway to central Asia (the giant hub of oil production) it holds great potential to take part in the politics of oil (Rousseau, 2011). China is playing smartly here for that matter and investing billion dollars in constructing a huge corridor as a part of its One-Belt-OneRoad (OBOR) initiative, famous as China Pakistan Economic Corridor (Long Term Plan for China Pakistan Economic Corridor (2017-2030), 2017). Being located at this point of the region, Pakistan has got all what it takes to become the vibrant transit economy (Mustafa). More importantly, Pakistan has a prominent strategic position in the Islamic world that makes it key role player in participating economic activities. Being the only Islamic nuclear power makes it strong enough to play the significant role in combating terrorism from the region as well (Defence P. , 2013). 


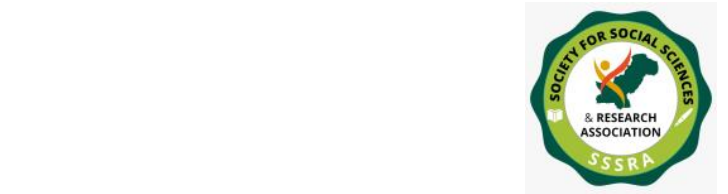

Pak. Journal of Int'L Affairs, Vol 4, Issue 2 (2021)

The Conundrum of Pak-Afghan Border ...

\section{AFGHANISTAN}

Afghanistan is likewise significant for it lies contiguous the Middle East and Central Asian nations who have the greater part of the world's all out oil holds (Defense M. o., 2011). The nation imparts its line to Iran and Turkmenistan, the nations who are the world's second and third biggest makers of flammable gas (Duddu, 2013). The pipeline course for the transaction of gas is one of its sort significant financial contentions particularly in this space where two of the world's biggest gas holds are available (Than and Kahn, 2015). Afghanistan, in this fight for international fight, is an essential piece of genuine state. Likewise, Iran has proposed a pipeline that may transport the gas to Pakistan and India as a giant alternative of the already proposed pipeline supported by the US from Turkmenistan through Afghanistan to Pakistan and India. So in other words, a huge game of energy and power is underway where Afghanistan holds an uttermost strategic importance so far. Many sane voices who have a great insight of the geopolitics of this region raise this question quite at times that what is the motivation behind the US staying for too long in Afghanistan, is it to combat terrorism, showing muscles to the rogue elements or is it due to grabbing a stout access to the energy reserves (Foster, 2009).

Based on the above mentioned geostrategic importance of both the countries it is certain that both countries have their own respective identities and role in the region. It is yet again a fact that both the countries, especially Afghanistan need to recognize that none of the countries can be undone from the world map. The arrangements of the boundary gives that have been drawn out among Pakistan and Afghanistan and should settle down gave the way that the political interests of both the nations should not be compromised.

\section{AN OVERVIEW OF PAK-AFGHAN RELATIONSHIP OVER TIME}

In the opinion of (Ahmad S. , 2015), Pakistan, just get-togethers intrusion, appeared to have sought after the few objectives in Afghan clash incorporating drawing nearer in attach with Mujahedeen in the conflict against the Soviets, persuading the Pushtoons on the opposite side of the boundary to come nearer to Islamabad so it might influence them to pull out with their standard nonconformist case, energy up the counter Indian slant, expanding the battling capacity to the degree of becoming atomic force and so on Adding to that, Pakistan from the principal day of its origin has been in a simple help of gripping amicable associations with the other Muslim nations as a significant thought of its international strategy. Nonetheless,, Afghanistan supported the negative mentality despite their common pilgrim heritage. There is a fiery series of events as part of the bilateral relationship between the two countries which in the opinion of (Javaid, 2016) have a 


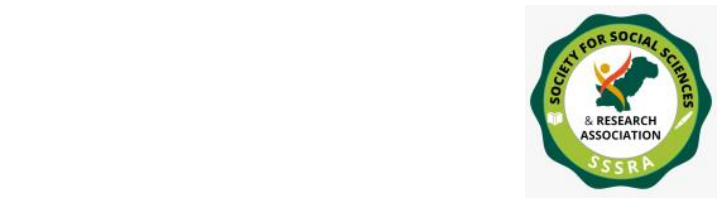

The Conundrum of Pak-Afghan Border ...

strong correlation with three important factors including Pre-Colonial Impacts, Political change after the emergence of Pakistan on global map and Post 9/11 impacts.

\section{THE COLONIAL LEGACY AND PAK-AFGHAN BORDER}

It is a composed truth in the set of experiences that Afghanistan was utilized as the cradle zone against the immense white brew in South Asia by the British government, by and by, in spite of this savage reality, the monarchial government had been found calm in Afghanistan and British pioneer ace (Javaid, 2016). The issue of Durand Line after the partition was the new impetus to the silent hostility taking place in Afghanistan. Denying Durand Line to become a permanent border and the logic behind that could not be happily conceived by Pakistan. So the strong and furious claims over the geographical borders have multiple types of elucidations so far (Rahi, 2014). The Afghan stakeholders believed in the permanence of Durand Line, however, the creation of Pakistan in 1947 led to the famous Pashtunistan stunt. Interestingly, it is remembered as the event in which Afghanistan claimed the ownership over the North-West Frontier Province of Pakistan (Khuhro, 2012). It was the reason behind Afghanistan being the only country voting against Pakistan in the United Nations (Clements \& Adamec, 2003). The reason behind Pakistan claiming the NWFP region currently named as Khyber Pakhtunkhwa (KPK) was its opinion that there were more Pashtun community representatives abiding in Pakistan than in Afghanistan. This later on affected the bilateral relationship between the neighboring countries a big-time (Javaid, 2016). This is profoundly corresponded with the authentic Franco-Afghan conflicts in nineteenth and twentieth hundreds of years in which the hostility against Pakistan was profoundly established where British forces were assuming responsibility for the geological space of Pakistan when Pakistan didn't arise on the worldwide guide.

\section{EVENTS AFTER THE EMERGENCE OF PAKISTAN ON GLOBAL MAP}

As it has been examined before that keeping up with well-disposed relations with all adjoining states overall and Muslim states points of interest is a fundamental standard of Pakistan international strategy yet Afghanistan slighting this expectation of Pakistan had an exceptionally reality check on the day when Pakistan must be acknowledged as a free state. Afghanistan wouldn't acknowledge Pakistan's freedom as well as casted a ballot against it in the United Nations (Durani and Khan, 2009). It guaranteed the responsibility for entire NWFP, Baluchistan and a few spaces of Punjab and furthermore interrogated the understanding concerning Durand Line that was endorsed to formalize Afghanistan's Frontier with the British-managed Hindustan (Ahmad N. , 2016). 


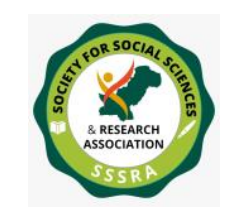

Pak. Journal of Int'L Affairs, Vol 4, Issue 2 (2021)

The Conundrum of Pak-Afghan Border ...

Critically, Kabul proclaimed Durand Line to be the nonexistent line on July 26, 1949, voiding every one of the arrangements that were supported already (Shah, 2017). In any case, these cases went un-saw that time as the world had continued on from the standard, worn out molded eighteenth century international relations (Ahmad N. , 2016). The point to be mentioned here is that Afghanistan as a matter of fact never tried to breach the bequest of Durand Line. Adding to that, the Soviet-supported Pashtun drive kept on insisting for the denial of Pakistan's legitimacy on NWFP. Indian support for the Nationalist still haunts Pakistan to lose its most important region (Indian Intervention may make or break Baloch Nationalist Movement, 2016). However, the gurus of world politics are of opinion that Afghanistan can never displace its post-colonial neighbor (Ahmad N. , 2016).

\section{POST 9/11 WAVES}

The attack on Twin-Tower in the United States of America instigated a new wave of insurgency and terrorism in FATA and KPK (Chakrabarti, 2014). The continuous strikes of the US-led forces made Afghanistan to again become a battlefield (RFE/RL, 2017). Those strikes encouraged the people of Afghanistan to move and take shelter in Pakistan, FATA and KPK to be specific (Reliefweb, 2017). It included the terrorist groups as well for whom it was not a difficult task to enter Pakistan crossing mountains and the terrain area. Adding to that, Pakistan supported the USA in the war against terrorism in Afghanistan (Katz, n.d.). This support of Pakistan for the US provoked some local militant wings to make an alliance with those who came from Afghanistan and started creating chaos in Pakistan. Kidnapping, robbery, and violence became the fashion of the day. All this had a very strong impact on the socioeconomic and political vista of the present time (Gold, 2004).

The rogue militia proudly challenged the writ of the state. Mullah Fazlullah started violent activities in the name of Islam in KPK, FATA, and Malakand division calling it Tehreek-e-Nifaz-e-Sharia-e-Muhammadi (May peace be upon him) (TNSM). This group created some self-designed pseudo courts calling them Islamic courts, however, they had no legitimate nexus with Islam (Khan, 2010). They would first announce some self-made law and then brutally punish the one who disobeyed it. Their illegitimate activities in the name of Islam demolished the infrastructure and socioeconomic conditions on a greater scale (Ali \& Khan, 2010).

The Pakistani government and Law Enforcement Agencies decided to counter these rogue elements, thus started the great military operation to deal with these militant wings. This operation made many people to become internally displace to Mardan and Swabi 


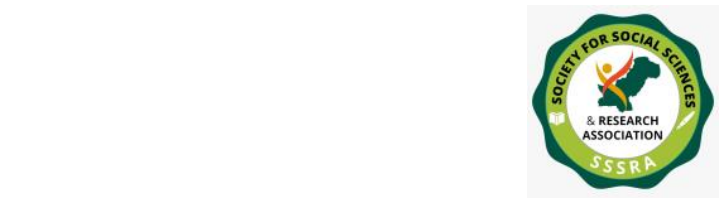

Pak. Journal of Int'L Affairs, Vol 4, Issue 2 (2021)

The Conundrum of Pak-Afghan Border ...

regions. It affected the tourism in the country and not only that but the revenue that could be collected on behalf of tourist activities once in a great amount lowered down to zero. Pakistan suffered a lot in this whole war on terror started right after 9/11, the attack that was executed from Afghanistan (TheNews, 2018). Moreover, the barbaric and inhumane terrorist attacks like that of Army Public School Peshawar was planned from Afghanistan and then many other small and big episodes of terrorism kept on to be produced from Afghanistan on the territory of Pakistan. All this has influenced the relationship between the two countries to still remain unresolved.

\section{THE LEGACY OF DURAND LINE: Discussion about Issues and Solutions}

Borders are the most devastating and enduring legacy of the European Colonialism's five centuries for borders were sketched with the intention of political and military expediency but in today's time, they make no proper sense provided the region's underlying history, culture, and ethnicity. In the nineteenth century, Afghanistan was used as a pawn for the "Great Game" going on between Great Britain and Russian Empire to gain the control of Central Asia. The Great Britain attacked Afghanistan twice to be crushed by a guerilla Army that was drawn initially from the Pashtoon clans living in the area as in to block any further Russian development south. The Great Britain, trying to get the control of the system Khyber Pass, in 1983, dispatched a British representative, Mortimer Durand so that he may negotiate with Afghanistan to make an agreement to sketch a border between Afghanistan and British ruled India (Micallef, 2015). This borderline was named as Durand Line dividing the Pushtunistan into two halves, one to be the part of Afghanistan and another one to be the part of British India which had to become the part of Pakistan after the partition in the sub-continent (Schons, 2011). The agreement was declared void later on by Afghanistan calling Durand Line to be just the imaginary one. Afghanistan had to lose the access to the Arabian Sea as it had to lose the province of Baluchistan to British India (now Baluchistan is the part of Pakistan). This Line separated the Russian Empire from British India ensuring the presence of the thin strip of Afghanistan running to the Chinese border. So this is going to be one of the top most agendas of Afghanistan in its future politics (Micallef, 2015). Provided this possibility and based on the predictions, Pakistan must also have some political stance handy to deal with this matter in a sage.

\section{CONCLUSION}

The empty sockets in the literature about this important political matter need to be plugged in with more research and discussion, however, given some evidences from the history, we can conclude it on the note that the importance of both the countries should 
be kept in mind while making any decisions. To avoid this border dispute to become another Kashmir like an issue for Pakistan, a healthy dialogue is required where the smartest of the think tanks from both the countries should sit on one table to find out the logical solutions. It is hereby important to mention that Afghanistan will have to be a little flexible as there are other important developments are taking place in the region where the construction of China Pakistan Economic Corridor needs to be mentioned on top as it has to be a Game Changer for the geopolitics of the region. China and Pakistan are seriously thinking about the inclusiveness of the other actors of the region among which Afghanistan is at the top of their list (Blanchard, 2017). The future wars will be conquered on the economic prosperity and for that, mutual cooperation is one important factor to drive the individual countries toward success. Continuing the rigidity will result in issues to stay in the cold storage instead of moving toward solutions. 


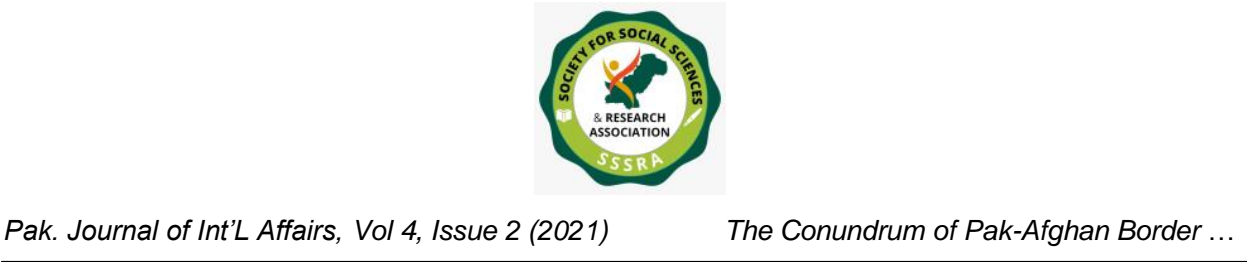

\section{References}

Ahmad, N. (2016, June 21). Analysis: The Grim Reality of Pak-Afghan. Retrieved from The Express Tribune: https://tribune.com.pk/story/1127035/analysis-grim-reality-pakafghan-relations/

Ahmad, S. (2015, October 11). Fixing Afghanistan-Pakistan Relations. Retrieved from Daily Times: https://dailytimes.com.pk/98113/fixing-afghanistan-pakistan-relations/

Ali, L. A., \& Khan, I. N. (2010). The Rise of Tehreek-e-Nifaz-e-Shariat-e-Mohammadi in Malakand Division, NWFP: A Case Study of the Process of "State Inversion". Pakistan Vision.

Bashir, S., \& Crews, R. D. (2012). Under the Drones. Harvard University Press.

Blanchard, B. (2017, December 25). China, Pakistan to look at including Afghanistan in \$57 billion Economic Corridor. Retrieved from Reuters:

https://www.reuters.com/article/us-china-pakistan-afghanistan/china-pakistan-to-lookat-including-afghanistan-in-57-billion-economic-corridor-idUSKBN1EK0ES

Chakrabarti, K. (2014, February 14). There is an Insurgency in FATA. Retrieved from Friday Times: http://www.thefridaytimes.com/tft/there-is-an-insurgency-in-fata/

Chaudhry, N. (2017). The Localised Madrasas of Afghanistan: their Political and Governance Entanglements. Religion, State and Society.

Clements, F., \& Adamec, L. W. (2003). Conflict in Afghanistan: A Historical Encyclopedia. ABC-CLIO.

Defence, M. o. (2011, April). Analysis document of the IEEE 12/2011 Geopolitical Analysis of Afghanistan. Retrieved from IEEE:

http://www.ieee.es/en/Galerias/fichero/docs_analisis/2011/DIEEEA12-

2011_Geopolitica_AFganistan_GBBallesteros_ENGLISH.pdf

Defence, P. (2013, August 06). Geo-Strategic Significance of Pakistan. Retrieved from Pakistan Defence: https://defence.pk/pdf/threads/geo-strategic-significance-ofpakistan.269246/

Duddu, P. (2013, November 11). The World's Biggest Natural Gas Reserves. Retrieved from Hydrocarbons Technology: https://www.hydrocarbonstechnology.com/features/feature-the-worlds-biggest-natural-gas-reserves/ 


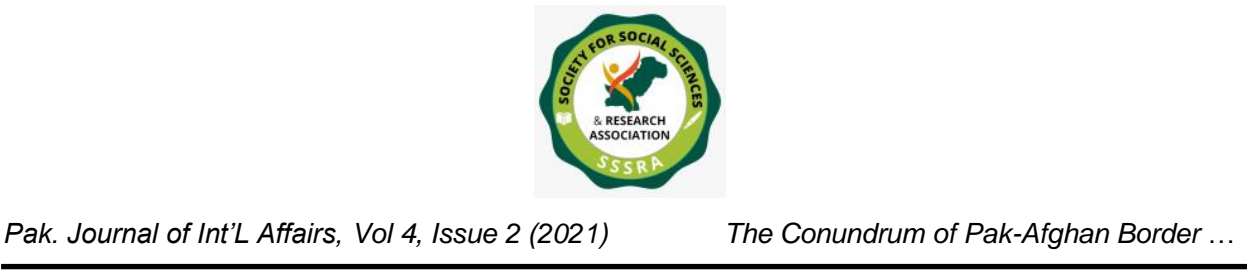

Durani, M. U., \& Khan, A. (2009). Pakistan - Afghan Relations: Historic Mirror. The Dialogue.

Foster, J. (2009, August 17). Why is Afghanistan strategically so important to the West? Retrieved from Stratford Beacon Herald: http://www.stratfordbeaconherald.com/2009/08/17/why-is-afghanistan-strategicallyso-important-to-the-west

Gold, D. (2004). Some Economic Considerations in the U.S. War on Terrorism. World Policy.

Haider, M. (2013, July 20). European Parliament Identifies Wahabi and Salafi Roots of Global Terrorism. Retrieved from Dawn: https://www.dawn.com/news/1029713

Hussain, Z. (2017, February 22). War of sanctuaries. Retrieved from Dawn: https://www.dawn.com/news/1316222

Indian Intervention may make or break Baloch Nationalist Movement. (2016, August 16). Retrieved from The Quint: https://www.thequint.com/news/world/indian-interventionmay-steal-balochistan-movements-age-old-thunder-narendra-modi-nawaz-sharifprime-minister

Javaid, U. (2016). Analyzing the Dynamics of Pakistan-Afghanistan Relations: Past and Present. South Asian Studies, 137 -147.

Katz, M. N. (n.d.). Pakistan and the "War on Terror". Retrieved from Middle East Policy Council: http://www.mepc.org/commentary/pakistan-and-war-terror

Khan, N. I. (2010). Tehreek-i-Nifaz-i-Shariat-i-Muhammadi in Malakand Division (Khyber Pakhtunkhwa): A Case Study of the Process of "State Inversion". Pakistan Journal of History and Culture.

Khuhro, Z. (2012, March 23). A Case for Realpolitik. Retrieved from Express Tribune: https://tribune.com.pk/story/354100/a-case-for-realpolitik/

Kundi, D. M. (2016). Pak-Afghan Borderland Interaction: Alone Together. Margalla Papers.

Kundi, M. A. (2016). Pak-Afghan Borderland Interaction: Alone together. Margalla Papers 2016.

(2017). Long Term Plan for China Pakistan Economic Corridor (2017-2030). Government of Pakistan Ministry of Planning, Development and Reform and People's Republic of China National Development and Reform Commission. 


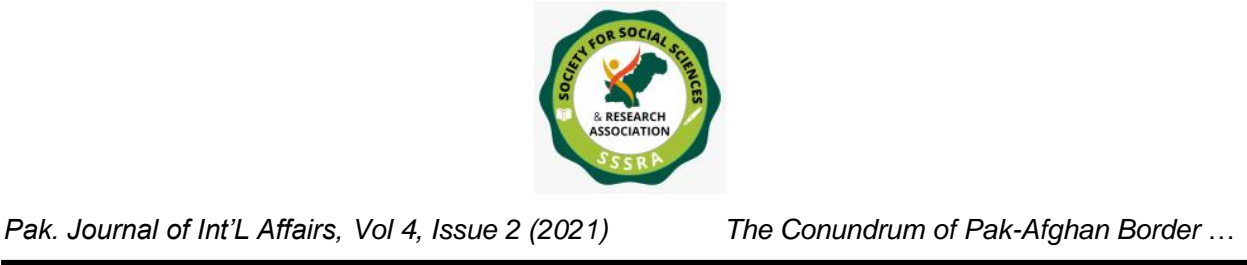

Micallef, J. V. (2015, November 21). Afghanistan and Pakistan: The Poisoned Legacy of the Durand Line. Retrieved from Huffingtonpost:

https://www.huffingtonpost.com/joseph-v-micallef/afghanistan-and-

pakistan_b_8590918.html

Mustafa, C. G. (n.d.). Pakistan - An Important Logistic Hub for Transit Trade. Retrieved from piffapk: http://www.piffapk.com/downloads/reports/Article-CaptGhulamMustafaWaterlink.pdf

Nytimes. (20, June 2011). The Strategic Importance of Pakistan. Retrieved from The New York Times: https://www.nytimes.com/2011/06/21/opinion/21iht-edlet21.html

Omrani, B. (2009). The Durand Line: History and Problems Of the Aghan-Pakistan Border. Asian Affairs.

Opec. (2016). Opec Share of World Crude Oil Reserves, 2016. Retrieved from Opec: http://www.opec.org/opec_web/en/data_graphs/330.htm

Rahi, A. (2014, February 21). Why the Durand Line Matters. Retrieved from The Diplomat: https://thediplomat.com/2014/02/why-the-durand-line-matters/

Rais, R. B. (2017). Geopolitics on the Pakistan-Afghanistan Borderland: An Overview of Different Historical Phases. Geopolitics.

Reliefweb. (2017, December 31). UNHCR Pakistan Fact sheet, December 2017. Retrieved from Reliefweb: https://reliefweb.int/report/pakistan/unhcr-pakistan-fact-sheetdecember-2017

Reuters. (2018, January 6). Terrorists are as much a threat against Pakistan as they are to us: Mattis. Retrieved from Express Tribune: https://tribune.com.pk/story/1602140/1terrorists-much-threat-pakistan-us-mattis/

RFE/RL. (2017, December 17). U.S. Hails Afghan Forces'Battlefield Gains, Urges Taliban To Seek Talks With Kabul. Retrieved from RadioFreeEurope/RadioLiberty: https://www.rferl.org/a/us-afghanistan-taliban-nato-ghani-andsf/28922618.html

Rousseau, R. (2011, June 24). Pipeline Politics in Central Asia. Retrieved from Foreign Policy in Focus: https://fpif.org/pipeline_politics_in_central_asia/

Rubin, B. R., \& Siddique, A. (2006). Resolving the Pakistan- Afghanistan Stalemate. United States Institute for Peace. 
Schons, M. (2011, January 21). The Durand Line: Disputed border separates Afghanistan and Pakistan. Retrieved from National Geographic: https://www.nationalgeographic.org/news/durand-line/

Shah, S. (2017, May 09). History, Controversies Linked to 114-year-old Durand Line Pact. Retrieved from The News: https://www.thenews.com.pk/print/203283-Historycontroversies-linked-to-114-year-old-Durand-Line-pact

Than, K., \& Kahn, M. (2015, February 15). Pipeline Politics: New Gas Route Revives Russian Rivalry with West. Retrieved from Reuters: https://www.reuters.com/article/us-russiagas-europe-idUSKBNOLS25620150224

TheNews. (2018, March 27). 'Pakistan Suffered Colossal Losses as Frontline State in War on Terrorism'. Retrieved from The News: https://www.thenews.com.pk/print/297023pakistan-suffered-colossal-losses-as-frontline-state-in-war-on-terrorism Yousaf, K. (2018, May 7). Pakistan's Pivot to Russia. Retrieved from Express Tribune: https://tribune.com.pk/story/1704034/6-untold-story-pak-russia-bonhomie/ 